Ethiopian Journal of Environmental Studies \& Management 10(1): 89 - 100, 2017.

ISSN:1998-0507

doi: http://dx.doi.org/10.4314/ejesm.v10i1.9

Submitted: October 14, 2016

Accepted: January 24, 2017

\title{
INVESTIGATION OF POTENTIAL SOURCES OF CONFLICTS FROM JOINT FOREST MANAGEMENT OF THE ILA LOCAL FOREST IN NAMWALA, ZAMBIA
}

\author{
*NDULINGA, P.1 AND MWITWA, J.2 \\ ${ }^{1}$ Dag Hammarskjöld Institute for Peace and Conflict Studies, Copperbelt University, P.O. Box \\ 21692, Kitwe, Zambia \\ ${ }^{2}$ School of Natural Resources, Copperbelt University, P.O. Box 21692, Kitwe, Zambia
}

\begin{abstract}
This paper investigates the potential sources of conflicts of Joint Forest Management in the Ila local forest, Namwala, Zambia. Joint Forest Management was implemented with the intention of involving local communities in the management of forest resources. Although these policies were intended to devolve the control and responsibilities of the state agencies to the local communities in management of the forest resources, the results showed that communities did not participate fully as they were left only with a role of consultation and conducting forest patrols with little or no incentives. Primary data was obtained through the use of questionnaire surveys, focus group discussions and observations. A total of 100 questionnaires were administered and 7 interview guides were administered on the stakeholders; namely, NGOs, CBO and some government agencies. Data was analysed using SPSS and presented in form of tables, graphs and pie charts. The study revealed that the illegal forest activities had increased with the introduction of JFM while the livelihoods of the local community did not improve. Subsequently, the lack of benefits and decision making power by the community over management of the forest resources made it impossible for them to appreciate the programme, and instead opted to continue with the illegal forest activities. There was little or no participation of all stakeholders in the programme leading to unsustainable forestry management. The study concludes that the conflicts surrounding the implementation of JFM in Zambia if not addressed would make it difficult to achieve the intended objectives of the approach.
\end{abstract}

Key Words: Joint Forest Management, Decentralisation, Stakeholder Involvement

\section{Introduction}

Despite forests playing a fundamental role in sustaining society time immemorial (CIFOR, 2005), their destruction for timber, cropland, fuel wood, pasture, urbanization and commercial industry (Poffenberg, 2011) has had a negative impact on both humans and the ecosystem at large. The growing scarcity of forest resources has made forests to be sites of conflicts between states and the people whose livelihoods depended on these resources (Menzi, 2004). These conditions have intensified and now contributing to the escalation of conflicts over control and 
use of the natural resources (Mola-Yudego and Gritten, 2010).

However, world over, there are new opportunities for local people to participate in sustaining forests in ways that were not anticipated some decades ago (FAO, 2000). According to Wily (2001), the continued decline of forests has fostered the search for new strategies that would stem the trend and place the remaining forests under secure and effective management.

While the decentralized policies were seen to be an option to the degradation of natural resources and the dwindling economic hardships experienced by the rural people, Yasmi (2003) argues that the co-management can set into motion new conflicts or allow old ones to escalate as different interests, knowledge levels and world views are incorporated. To support the assertion, Cronkleton et al. (2012), have pointed out that the strategies and actions adopted by state actors for the decentralized policies often create faulty outcomes, undercutting their results and limiting their impacts. The study acknowledged that participatory approaches world over were adopted with the intention of achieving effective management of natural resources through the involvement of local communities. However, in Zambia, the implementation of the JFM in the Ila local forest was marred with challenges resulting into conflicts. It is therefore, important that the Forest Policy be revised to provide for other stakeholders especially the local community to have full control over forestry resources management such as issuing of permits / licensing.

This study was aimed at providing information on the sources of conflicts arising from the implementation of JFM and how the implementation of JFM would improve the wellbeing of the local community. The objectives were (i) to evaluate the role of the implementation of JFM and conflict resolution in forest resources management; (ii) to investigate types of conflicts associated with the implementation of JFM; and (iii)to identify the key stakeholders, their rights and obligations and the extent to which these are reflected in the implementation of JFM.

\section{Approaches to Forestry Resources Management}

The dominant approach to conservation of nature in the 20th Century was the Protected Area Model often referred to as "Fortress Conservation" (Brockington, 2002, Wily, 2001; Adams, 2001), which was restrictive of the people's management. Under, this approach, the indigenous people who were the custodians of the forests at that time, were alienated from their ancestral land and denied access to forests and the associated resources. They were instead pushed to marginal lands which were unproductive (Brockington and Igoe, 2009), there by igniting conflicts between state governments and themselves. Interests of the people often had to make way for the interests of conservation. The forests which were regarded as government resources further created more conflicts between the potential users and government officials, leading to the former encroaching on public gazetted forests to which they viewed their access as unjustifiably denied. This state of affairs became widespread in many Developing countries including Asia, Latin America and African countries.

Meanwhile, the failure of the state governments to halt, let alone to reverse the continued loss of the forest resources or to prevent degradation of those forests 
which were under their own auspices, stimulated the idea of involving communities in the management of the forests (Boonzaair, 2012). Therefore, the idea of community participation or Comanagement (Cronkleton et al., 2008) did not only become central to effective natural resource management but was also initiated to avoid the conflicts, while promoting sustainable management of natural resources. The limitation of the Protected Area Model resulted into focusing on Co-management.

Zambia like other African countries upheld the centralist approach, but management of the forests was not effective and sustainable as reported in the Integrated Land Use Assessments (ILUA) report of 2008, where the deforestation rate was found to be 250000 ha to 300000 ha per annum. In an effort to reduce the deforestation rate, participatory approaches were considered an alternative to management of the forest resources. As a result the Forest Policy of 1998 was aimed at integrating local community in management of the forests.

However, the participatory approaches in Zambia have been marred with conflicts between the implementing agencies usually government and the local community and or other stakeholders. Some of the conflicts identified include; weak leadership which culminates into internal conflicts among community members and between institutions, lack of fair and equitable benefit distribution mechanisms which often creates hostility among stakeholders and the inadequate income alternatives forcing the community to exploit the resources unsustainably.

Ribot (2004) and Pflugner (2010) conclude that decentralized management of natural resources have instead increased the vulnerability of the local people as management responsibilities are transferred without financial or institutional resources. It has been argued that for co-management to be effective, it should be an adaptive process that consists of negotiation, bargaining, or mediation and should provide an avenue for problem solving and learning. In this regard, many researchers have warned against seeing comanagement as a panacea for legitimacy (Jentoft, 2000). For example, Bene and Neiland (2006) have pointed out, that the track record of co-management is weak in poverty reduction and empowerment of the marginalized. The duo stated that comanagement and decentralization in general often lead to the support of local elite power or strengthening of state control. In addition, there must be stakeholder involvement in the management of these forest resources. Stakeholders can either be individuals, communities, social groups, government institutions, private sector, NGOs and the academia. Therefore, Adaptive comanagement can be considered as a form of multi-level governance, where different social actors at different territorial levels such as government (federal, regional and city governments), NGOs and international financial institutions share power and responsibility which can prevent conflicts (Benz, 2010). Hence co-management is not merely about resources, it is about managing relationships among all stakeholders involved.

\section{Materials and Methods}

A total number of 100 respondents (63 males and 37 females) were interviewed at community level. Many of the respondents were between the age range of 30 years and 60 years respectively. The interview began by informing the respondents the purpose of the study and seeking their 
permission to participate. They were guaranteed anonymity and confidentiality.

Data was collected at multiple levels using different methods. At the community level, the questionnaire was used and some focus group discussions. At institutional level such as the line Ministries and the Civic Society and the NGOs, focus group discussions and Key informants were used. The desk review was done from the scholarly written works such as the books and journals while secondary data was obtained from the institutional reports, records and maps. Data collected was analysed using the Statistical Package for Social Scientists (SPSS) and the open ended questions were organized according to themes and patterns and linking them to the objectives. Simple statistics such as percentages and mean were used to interpret the results. The results for both the qualitative and quantitative data were interpreted through tables, graphs and charts and then discussed.

Study Site (Ila Local Forest)

The Ila Forest Reserve No: P 40, has a total of 44,880 ha and covers most of the central part of the district, stretching into Itezhi-Itezhi district. The Forest Reserve is geographically located between $26^{\circ} 9^{\prime} 53^{\prime \prime}$ and $26^{\circ} 40^{\prime} 5^{\prime \prime}$ East; and $15^{\circ} 40^{\prime} 08^{\prime \prime}$ and $16^{\circ} 00^{\prime} 06^{\prime \prime}$ South (Figure 1). The forest covers a total land area of 34,309ha gazetted as National Forest and 10,571ha gazetted as Local Forest). The forest was established under Statutory Instrument No: 299 of 1966 and is managed by Forestry Department in the Ministry of Lands, Natural Resources and Environmental Protection (MLNREP).

Initially, the Ila National Forest was set aside by government and gazetted as a protected forest area for conservation purposes. However, part of the forest was downgraded from a national forest into a local forest $(10,570 \mathrm{ha})$ whose land use automatically changed for forest production. This is the area meant to provide the local community (people) with forest products such as timber under a commercial or casual forest license and non-wood forest products. Subsequently, JFM was introduced in the area in 2002 based on joint management and sharing of benefits derived from the forest reserve (PFAP, 2005). 


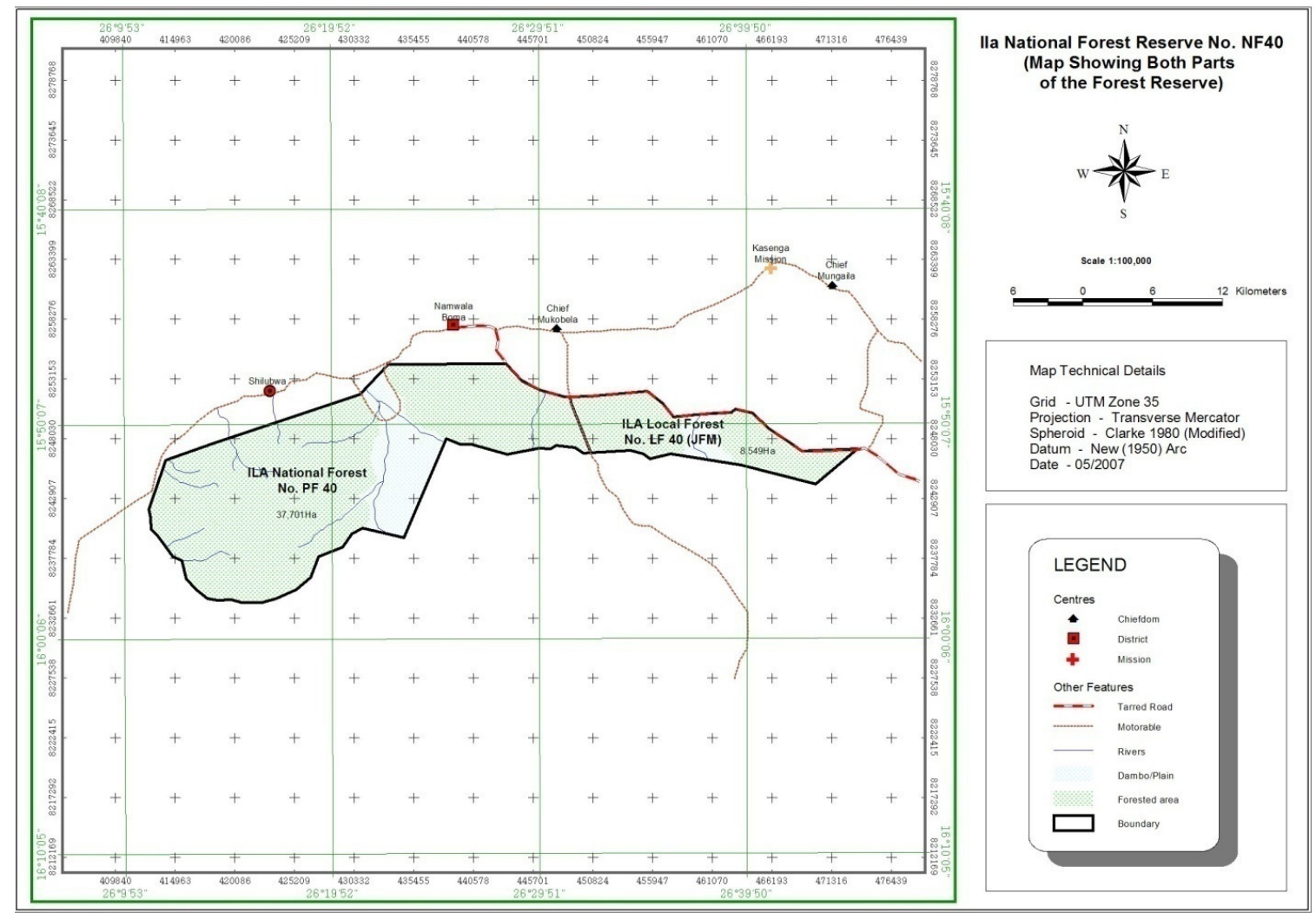

Figure 1: Map of the Ila Local Forest

Source: ILUA Report, 2008

\section{Results and Discussions}

The field data revealed issues pertaining to the following; status of the forest before and after JFM, illegal activities in the JFM area, Participation in the JFM, Perceptions whether JFM had achieved its objectives, Types of conflicts associated in the implementation of JFM and the Key stakeholders, their roles and responsibilities.

\section{Status of the Ila Local Forest before and} after JFM

When asked about the status of the Ila local forest after JFM, eighteen percent $(18 \%)$ were of the view that JFM had brought a reduction in the forest degradation, while $31 \%$ indicated that there was increased forest stocking. Fiftyone percent $(51 \%)$ reported that there were increased illegal activities resulting into high forest degradation (Figure 2). 


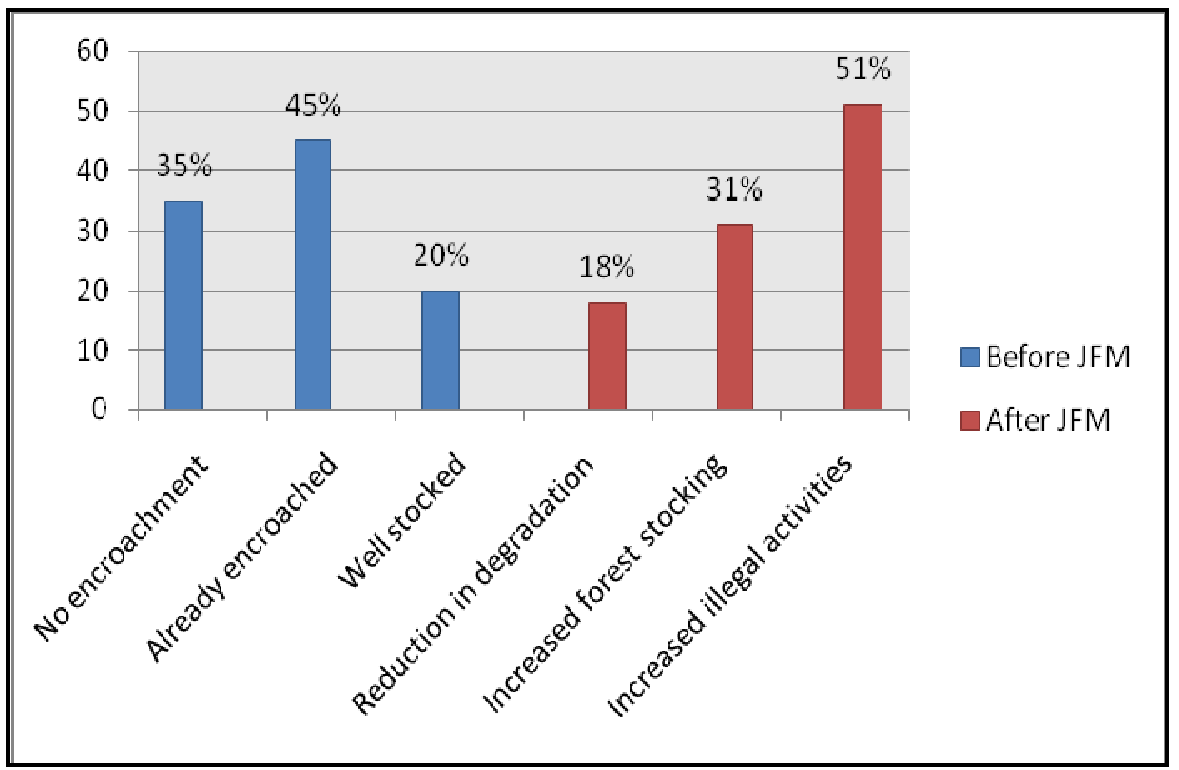

Figure 2: Status of the local forest before and after JFM

It can therefore be said that the conflicts between conservation objectives and the livelihood needs of the local communities are complicated and difficult to resolve and yet the success of either of the two depends on balancing them. Indeed, the scarcity of agricultural land to meet the needs of the expanding farmer population and also the lack of economic alternatives has often times resulted into increased pressures to encroach the forest reserves. On the other hand, as the pressure on arable land increases and soil fertility decreases, this too forces the local people to move into the forest areas where they think the soils are fertile. Today, many local forests and other protected areas have suffered the verge of encroachment. This was evident from the study, where $45 \%$ of the respondents in figure 2 reported that before JFM was introduced, there was already high rate of encroachment. While these factors could be true, encroachment into the forest reserve could also be as a result of weak law enforcement and lack of coordination among institutions.

\section{Participation in JFM}

Participation in JFM was not automatic, out of the 100 questionnaires distributed, $71 \%$ participated and $29 \%$ of the respondents did not participate. Sixtysix percent indicated they participated in JFM so as to reduce poverty while $28 \%$ indicated they participated so that there could be improved forest cover. Three percent $(3 \%)$ indicated they participated for various reasons such as (following others and going to learn something) while $2 \%$ of the respondents participated so that they could have access to benefits and a percentage $(1 \%)$ indicated they participated in order to have decisions over management of the resources.

For those who did not participate, $45 \%$ explained that they did not know what benefits were associated with JFM. However, $31 \%$ indicated there were no benefits for participation while $16 \%$ were of the view that participating in JFM was not a priority and $8 \%$ claimed the work was tedious. (figure 3 ). 


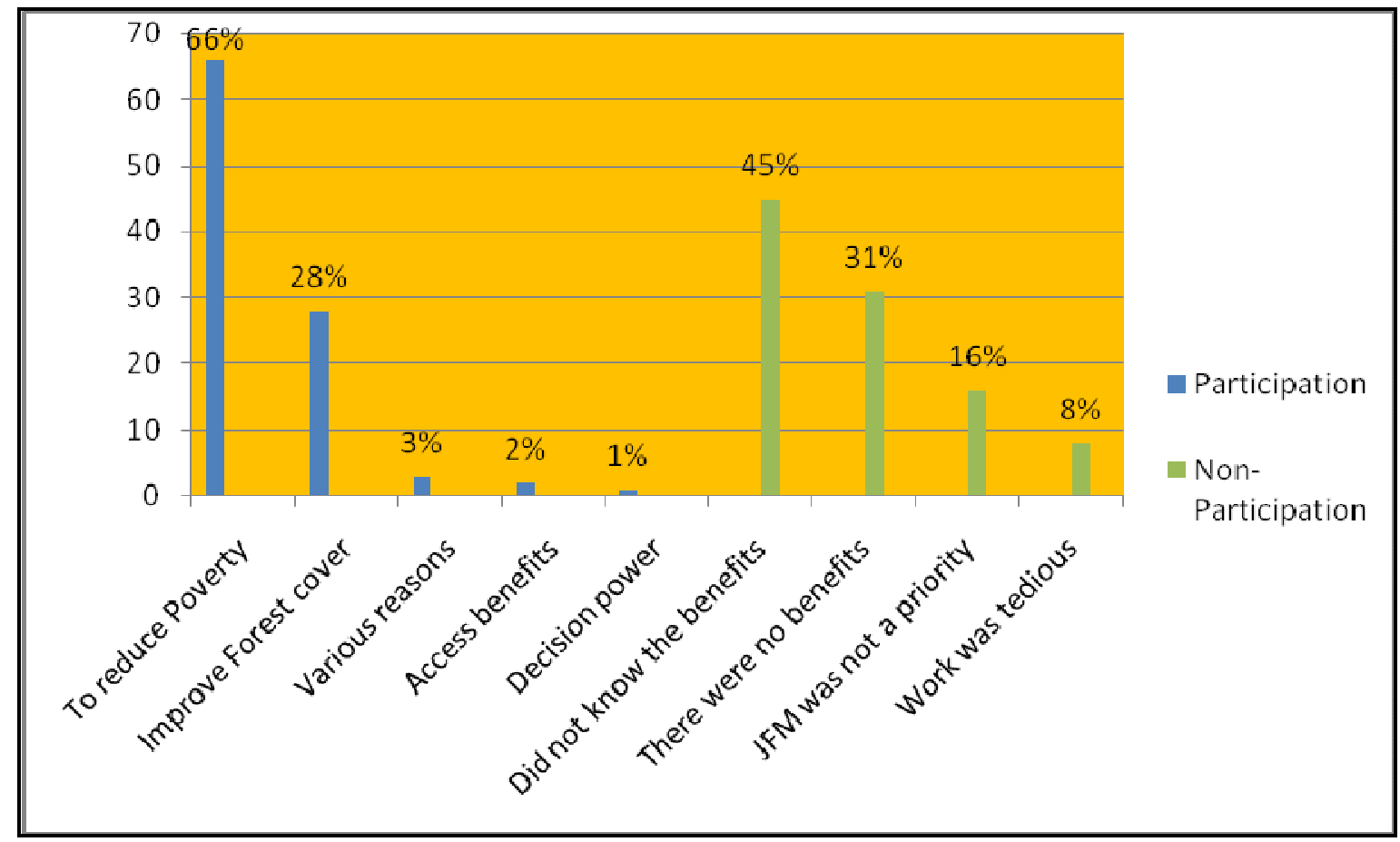

Figure 3: Reasons for Participation and non-Participation

It can therefore be said that the extent to which participatory approaches secure local people's support for conservation depends largely on the degree of involvement and the benefits derived from them. The intention of introducing JFM in Zambia and in the Ila local forest in particular was to involve the local community in the management of the forest resources and for them to influence management decisions while benefiting directly from conservation.

Like what Kellert et al. (2010) concluded that the inclusion of communities in the participatory approaches must enhance biodiversity conservation, the equitable distribution of benefits, conflict resolution, poverty reduction and indeed sustainable use. This is because the people living in these forest areas depend on the forests for a variety of their goods and services. Therefore, poverty reduction and sustainable livelihoods cannot be achieved where there is limited employment creation and income generating activities. Since indigenous people are carriers of ancestral knowledge and wisdom (Sobrevila 2008), effective participation of the local people should result in more comprehensive and costeffective management of forest resources. To the contrary, some local communities have misinterpreted the term 'participation', to mean attending meetings even when they do not influence any decisions. In most cases, women have fallen into this category where they have become passive participants.

\section{Perception of whether JFM had achieved its objectives}

Generally, JFM as a participatory approach was perceived not to have achieved its objectives as reported by sixty-five percent of the respondents. 
However, half (thirty-two percent) of this number indicated that JFM had achieved its objectives and only three percent were not sure, whether JFM had achieved its objectives or not (figure 5).

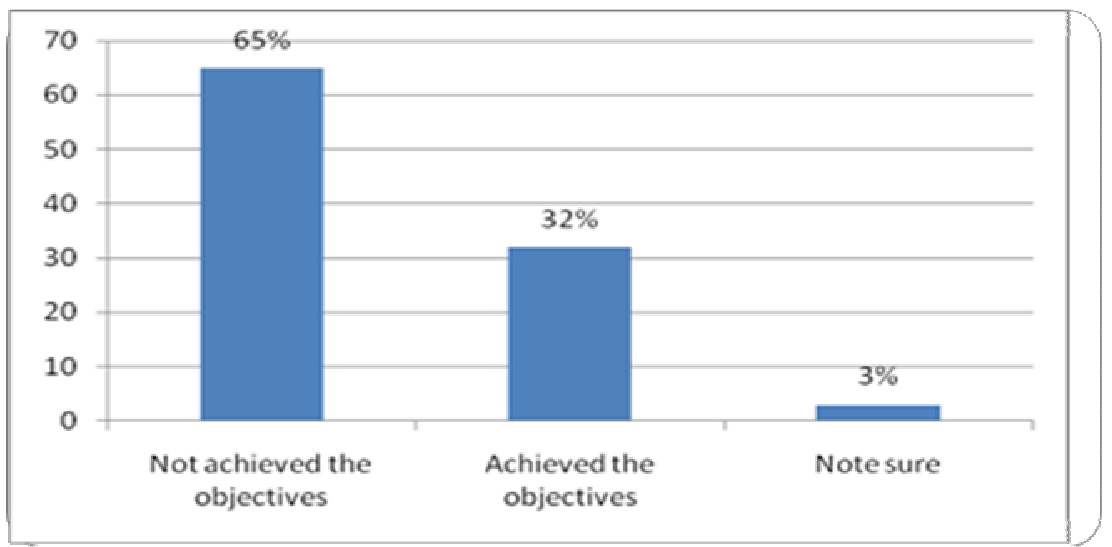

Figure 4: Perception of whether JFM had achieved its objectives

JFM in Zambia was envisioned to deliver two broad policy outcomes; namely, improved forest conditions and improved livelihoods (GRZ, 2005). Contrary to reports that JFM in Zambia had improved the forest conditions including livelihoods of the local community (Phiri, 2009; Bwalya, 2007), the study found that JFM in the Ila local forest did not achieve either the conservation objective nor the poverty reduction objective. This was because the forest resources which the rural people depended on were depleted due to rampant illegal forest activities. It is a well known fact that forests contribute significantly to the lives of the rural population through provision of timber and non-wood forest products. Since non-wood and wood products provide employment to the local community, thereby the depletion of these forest resources means depriving the local communities of their very livelihoods. According to Blomley (2006), forest resources were the principle assets of the poor, and the most proximate opportunity for poverty alleviation.
Types of conflicts associated with the implementation of JFM

Some of the identified conflicts associated with the implementation of JFM were structural in nature, whereby, they were embedded in the approach itself. These included, lack of benefit sharing mechanism, lack of land tenure and land ownership. Other types of conflicts were the inter-group conflicts between the local communities and the government. Intergroup conflicts were also identified between the local communities and those who were outside the local community. Yet intra-conflicts were experienced within the community regarding access to forest resources.

Key Stakeholders, their Rights and Obligations in the Implementation of JFM

Stakeholder involvement in the management of the forestry resources is very critical and must be supported. Apart from the local communities and other grass root structures such as the VRMCs and FMCs, seventy five percent of the respondents claimed there was need for stakeholder participation in the 
implementation of JFM, while twenty-five percent felt there was no need. For those who supported the need for stakeholder participation, identified stakeholders to include, local communities, VRMC, FRMC, Ministries, the Private sector, NGOs and Donor agencies. However, FD would not be considered a stakeholder, but an agency entrusted with management of forest resources. Therefore, seventy-eight percent of the respondents mentioned that all these stakeholders had a role to play in the implementation of JFM while twelve percent of the respondents did not know what roles each of those stakeholders played.

However, it is true that the current approach to the participatory forestry management has necessitated the need to involve a diversity of stakeholders in the sustainable forestry management. This would minimise the costs of conservation, while accruing economic and social benefits to the local community. When stakeholders are not involved, the tendency is that the old management regime where government was the sole owner of the forest resources usually prevails. Although the establishment of JFM in Zambia and Ila local forest in particular, was based on the tenets of stakeholders participation, this was not embraced. Stakeholder participation would improve forest governance by ensuring that the sustainable livelihoods of the local community are attained. As supported by Mogoi et al. (2012), that the exposure to PFM and its principles of involving the various stakeholders in decision making would make the community members in these pilot forest areas have a comparative advantage in terms of enhanced capacity in leadership, management and decision making. The local community can acquire knowledge from the trainings and workshops and can also be exposed to other experiences in the process of implementing various projects. Stakeholder holder involvement would include; Governments, Donors, International and Local NGOs, Private Sector, CBOs and the Local Community (Fabricus, 2004).

Indeed, the JFM programme is likely to succeed in terms of sustainability if the diverse groups of stakeholders within the programme are properly identified and aligned with the programme's goals.

\section{Conclusion}

The assumption that the decentralized approaches to management of resource would improve efficiency, equity, democracy in the management of the forest resources, instead proved that they often times had little or no positive impact on the lives of the local people for whom they were developed. The study found that there were usually conflicts between the objectives of the state in terms of management of forest resources and that of improving the livelihoods of the local people. While it is acknowledged that the local people in the Ila Local Forest could be involved in the management of the forest resources, the challenge however, was in balancing the demands of the local communities with the ecological concerns of the resource management. Indeed, a lot of thinking has gone into the theories and practices of JFM and a lot more work needs to be done.

The top-down or state control and lack of clear guidelines to transfer the rights to the local communities are still evident in the management of the forest resources in Zambia. Additionally, ownership of forests has remained with government while only management has been participatory. This has brought about 
natural resources conflicts which are now an area of concern by all stakeholders in the forestry sector. Conflicts have arisen because of unclear roles for the local community and other stakeholders, lack of benefits (both monetary and nonmonetary) from the forest resources, no decision making power on the part of the local community, institutional gaps, poor governance and poor participation among the stakeholders. More specifically, the interests of civil society organizations, the private sector and other organisations have not adequately been considered in the participatory policy. In as much as conflicts in forest management may be inevitable due to the multiple-function and multiple use of nature of forests, it is important to understand their implications on the lives of the people who are dependent on these forests. Therefore, management of the forest resources should be understood as a collection of decisions, practices and concepts that should go beyond the immediate resources use with future intent. This entails that there should be participation of all stakeholders in the sustainable forest management.

It is well acknowledged that the Forestry Department has failed to manage the forest resource due to limited resources both financial and human. It is imperative, therefore, that other stakeholders could come on board in the management of these resources. However, the findings were that there has been limited coordination among stakeholders in particular among government agencies, NGOs, the private sector and the local communities. Worse still, JFM in the Ila Local Forest could not achieve its objectives, because it was poorly coordinated by the Forestry Department and the District staff were not adequately strengthened both financially and technically for them to implement the programme efficiently on the ground. It was noted that they rarely monitored work because of lack of transport.

On the other hand, it is important to know that the participation of all stakeholders such as the local community, NGOs, CBOs and the private sector in the management of forest resources, would ensure continuity and expansion of the programme to other parts of the country. However, caution must be taken that stakeholder participation in forest resources management is not considered a blue print to sustainable forestry management. This is because forests represent a typical mixture of commonpool resources which are toll goods and purely public goods, such that local-level community management systems would be the most appropriate for sustainable forest management while the centralised management systems may also not be desirable.

\section{Recommendations}

1. The success of JFM would depend not only upon effective forest laws and policies, but also on support from other laws and policies. These would include laws governing the land, wildlife, fisheries, local trade and marketing and cooperative activities.

2. Participation must be inclusive involving all stakeholders at all stages of planning and implementation.

3. The Forest Policy must be explicit on land tenure and forest ownership. This is a critical issue to the communities and as long as forest ownership is not delegated, incentives to participate in forest management would be low.

4. The Forestry Department should provide clear guidelines on the benefit sharing mechanisms. The local community would only commit 
themselves in management of the forest resources, once they see that the costs involved do not outweigh the benefits to be realized.

5. JFM should strengthen the local level structures such as the VRMCs and also find innovative ways of making the women and other vulnerable segments of the community to be heard in the process of crafting rules and regulations for community forest management.

6. For JFM to be understood and appreciated there is need for public awareness to both the Local communities and the general public at large. This is so because JFM in Zambia is still evolving, not much has been done and the local communities are all expectant.

\section{Acknowledgements}

We acknowledge the support of the Dag Hammerjoid Institute for Peace Studies (DPIS), Copperbelt University. The insights of the members of staff and the anonymous reviewers of the EJESM for their valuable comments which helped improve the quality of this paper. We continue to be grateful to the communities we worked with during the surveys.

\section{References}

Adams, W.M. (2001). Greener Development: Environment and Sustainability in the Third World. Routledge. London.

Bene, C. and Neiland, A. (2006). From Participation to Governance. $A$ critical Review of Governance, CoManagement and Participation in Natural Resources Management: Policy, Economics and Social Science Discussion Paper Series. 74;
World Fish Centre: Penang,
Malaysia. Benz, A. (2010). Multi-level Governance. Governance in Mehrebenen system. In: Benz, A and Dose, $\mathrm{N}$ (eds.). Governance. Regieren in Komplexen. Rogel system Wisebaden.

Blomeley, T. and Ramadhani, H. (2006). Going to scale with participatory forestry management: Early Lessons from Tanzania. International Forestry Review.

Boonzaier, C.C. (2012). Towards a Community Based Integrated Institutional Framework for Ecotourism Management: A case of Masebe Nature Reserve, Limpompo province of South Africa

Brockington, D. (2002). Fortress Conservation: The preservation of the Mkomazi Game Reserve, Tanzania. Oxford, James Currey.

Brockington, D. and Igoe, J. (2009). Eviction for Conservation: A Global Overview. West Manchester. United Kingdom

Bwalya, B. (2007). Katanino Joint Forest Management Area, Masaiti District. Zambia: Challenges and Opportunities. Norway University of Life Sciences. Norway.

Cronkleton, P., Pullin, J.M. and Saigal, S. (2012). Co-management in Community Forestry: How the partial devolution of management rights creates challenges for forest communities. Centre for International Forestry Research (CIFOR), Lima. Peru.

Cronkleton, P.P., Taylor, D., Barry, S. Stone-Jovicich and Schmink, M. (2008). Environmental Governance and the emergence of forest-based social movements. 
Fabricus, C. (2004). The Fundamentals of Community-Based Natural Resources Management. In Rights, Resources and Rural Development in Community-Based Natural resources Management in Southern Africa. Earthscan Publications Limited.

FAO. (2000). Participatory Forest Management. A Strategy for Sustainable Forest Management in Africa. Proceedings of the International Workshop on Community Forestry in Africa. 26-30 April, 1999. Banjul, The Gambia.

Government of the Republic of Zambia. Joint Forest Management Guidelines. (2005). Ministry of Tourism, Environment and Natural Resources. Lusaka. Zambia.

Integrated Land Use Assessment (ILUA) Report (2008). Ministry of Tourism, Environment and Natural Resources, Forestry Department, Zambia.

Jentoft, S. (2000). Legitimacy and Disappointment in fisheries management-prospects of User participation. Marine Policy.

Kellert, S., Mehta, J., Ebbin, S. and Litchtenfeld, L. (2000). "Community Natural Resources Management: Promise, Rhetoric ad Reality" Society and Natural Resources

Menzi，K.N. (2004). Communities and their Partners. Governance and Community-based Forest Management. University of Califonia, Bekeley USA

Mola-Yudego, B. and Gritten, D. (2010). Determining forest conflict hotspots according to academic and environmental groups. University of Eastern Finland. Joensuu. Finland.

Pfliegner, K. (2010). The Impact of Joint Forest Management on Forest Conditions, livelihoods and Governance: Case studies from Morogoro Region, Tanzania. University of East Anglia.

Phiri, M. (2009). Evaluation of the Performance of Joint Forest Management (JFM) Programme: The case of Dambwa Forest Reserve in Livingstone. Stellenbosch University. South Africa.

Poffenberg, M. (2011). Communities and Forest Management. A Report of the IUCN. Working Paper.

Ribot, J.C. (2004). Waiting for democracy: the politics of choice in natural decentralization. Washington. D.C. World Resources Institute.

Sobrevila, C. (2008). The role of Indigenous peoples in Biodiversity Conservation. The Natural but often Forgotten Partners. The International Bank for Reconstruction and Development / The World Bank. Washington, D.C USA.

Wily, A.L. (2001). Forestry Management and Democracy in East and Southern Africa: Lessons from Tanzania. Sustainable Agriculture and Rural Livelihoods Programme. UK.

Yasmi, Y. (2003). Understanding Conflict in the Co-management of forests: the case of Bulungan Research Forest. Jakarta, Indonesia. Centre for International Forestry Research. 